\title{
Sensitive and Quantitative Nitroblue-Tetrazolium Test for Detecting Chronic Granulomatous Disease
}

\author{
Naoki Okamura, Tatsuya Takano, Sadahiko Ishibashi, ${ }^{i a}$ ) \\ Daisuke Amano, and Tomofusa Usui ${ }^{1 b}$ \\ Department of Physiological Chemistry, Hiroshima University School of Medicine $\left.{ }^{1 a}\right)$ \\ and Department of Pediatrics, Hiroshima University School of Medicine ${ }^{1 b}$ )
}

(Received December 25, 1975)

\begin{abstract}
New method for nitroblue-tetrazolium (NBT) test was developed by the following modifications.

(1) After $10 \mathrm{~N} \mathrm{KOH}$ treatment, bathochromic shift in the maximal absorption took place from $515 \mathrm{~nm}$ to $710 \mathrm{~nm}$ and the optical density of the new peak was 5 times higher than that of non-treated sample. In this assay, dimethylformamide extraction was substituted for pyridine.

(2) Because of the smallness of the incubation mixture $(100 \mu 1)$, the background of the test was greatly reduced.

(3) Increase in the concentration of latex particles elevated the NBT reducing activity. In consideration with the background absorption, $2.9-5.7 \times 10^{8}$ particles/ assay was set as the optimal condition. The particles themselves, however, did not interrupt the reading of optical density in this system. In this modified method, $3 \mathrm{ml}$ of blood was enough to estimate the NBT reducing activity in the duplicate tests (6 samples). This assay system is, therefore, applicable for weak children, from whom the collection of the large volume of the blood is not desirable.
\end{abstract}

\section{Introduction}

Phagocytic and bactericidal activity of leukocytes is well known as an important defense mechanism against bacterial infection. It has been reported that the redox activity of leukocytes is involved in the bactericidal activity ${ }^{2}$ and that reducing activity of nitroblue-tetrazolium (NBT) relates to the redox activity. ${ }^{3)}$ It is also known that leukocytes of patients with chronic granulomatous disease (CGD) which can not kill bacteria, are defective in NBT reducing activity. ${ }^{4)}$ Thus, to detect such kind of patients, NBT-test has been used clinically in both biochemical and histochemical ways. In the case of weak patients such as baby patients, however, it is sometimes very undesirable to collect the blood so much as $15 \mathrm{ml}$ for the measurement in the ordinary NBT-test. It is required nevertheless to examine quantitatively the ability of NBT-reduction in leukocytes from such kind of patients.

The development of the sensitive NBT-test is not only useful in the clinical test but also in biochemical elucidation of the mechanism of the bactericidal function in polymorphonuclear (PMN) leukocytes. For these purposes, development of a sensitive NBT-test by the modification was attempted in the present study.

\section{Materials and Methods}

Preparation of Human Peripheral Polymorphonuclear (PMN) Leukocytes_-Human peripheral blood, $2-3 \mathrm{ml}$ and $20-25 \mathrm{ml}$, for the sensitive assay and ordinary assay, respectively, was collected with heparinized syringe, transfered into test tubes, and stood at room temperature for $1 \mathrm{hr}$ to let red cells sediment.

1) Location:a) b) 1-2-3, Kasumi, Hiroshima-shi, Hiroshima.

2) a) S.J. Klebanoff, J. Exp. Med., 126, 1063 (1967); b) R.C. Allen, S.J. Yevich, R.W. Orth, and R.H. Steele, Biochem. Biophys. Rec. Commum., 60, 909 (1974); c) N.I. Krinsky, Science, 186, 363 (1974).

3) J.R. Humbert, G.P. Gross, A.E. Vatter, and W.E. Hathaway, J. Lab. Clin. Med., 82, 20 (1973).

4) R.L. Baehner and D.G. Nathan, N. Engl. J. Med., 278, 971 (1968). 
The upper layer containing PMN leukocytes was transfered into another tube and mixed with 2 vol. of $0.87 \%$ (pH 7.4) ammonium chloride to disrupt contaminated red blood cells. The solution was mixed thoroughly, and centrifuged $(100 \mathrm{~g} \times 5 \mathrm{~min})$ immediately to collect leukocytes. The supernatant was aspirated off, and the cells were suspended in Krebs-Henseleit bicarbonate buffer ( $\mathrm{pH} 7.4$ ) (K-H buffer). The cells were washed twice and were resuspended in a small volume of the buffer. The number of PMN in the suspension was counted and $\mathrm{K}-\mathrm{H}$ buffer was added to make the number of PMN leukocytes adequate for the assay.

Preparation of PMN Leukocytes from Guinea Pig_-PMN leukocytes were prepared as method of Sbarra and Karnovsky. ${ }^{5}$ ) To induce the peritoneal leukocytes, $12 \%$ casein (Difco Lab.) in $0.9 \%$ NaCl solution (25 $\mathrm{ml} / \mathrm{kg}$ body weight) was injected intraperitoneally in guinea pigs (Hartley strain). After $18 \mathrm{hr}$, the peritoneal exudate was removed and was filtered through 4 sheets of gauze. In case red blood cells were found in the cell preparation, the cell suspension was treated with 2 vol of $0.87 \%$ ammonium chloride. The precipitate was washed with $\mathrm{K}-\mathrm{H}$ buffer twice, and the number of PMN leukocytes was counted. More than $95 \%$ of the cells were identified as PMN leukocytes under a light microscope.

The original latex particle suspension $(0.81 \mu$, Difco Lab.) was centrifuged $(1000 g \times 50 \mathrm{~min})$, and was resuspended in $\mathrm{K}-\mathrm{H}$ buffer to make the concentration of $2.4 \times 10^{11}$ particles $/ \mathrm{ml}$. The number of the latex particles was counted on the picture taken under a microscope.

Ordinary NBT-Test- The ordinary NBT-test developed by Baehner and Nathan ${ }^{4)}$ was examined as the control procedure. The following solution was mixed in test tubes to prepare the incubation solution; $\mathrm{K}-\mathrm{H}$ buffer $0.35 \mathrm{ml}, 0.85 \%$ sodium chloride containing $0.1 \% \mathrm{NBT}$ (Sigma Chem. Co. Grade III) $0.4 \mathrm{ml}$, and $0.01 \mathrm{M} \mathrm{KCN} 0.1 \mathrm{ml}$. To one of the tubes $0.05 \mathrm{ml}$ of latex particle was added (phagocytic series), to another $0.05 \mathrm{ml}$ of $\mathrm{K}-\mathrm{H}$ buffer was added instead of latex particles (resting series). Then $0.1 \mathrm{ml}$ of leukocytes suspension was added onto $0.9 \mathrm{ml}$ of incubation solutions." The reaction was allowed to proceed for $15 \mathrm{~min}$, and was stopped by the addition of $10 \mathrm{ml}$ of $0.5 \mathrm{~N}$ hydrochloric acid. The mixture was centrifuged $(1000 \mathrm{~g} \times 15$ $\mathrm{min}$ ) and the precipitate was extracted twice with $2 \mathrm{ml}$ of pyridine. Optical density of extracts was read at $515 \mathrm{~nm}$ against the no incubation blank. NBT reducing activity was calculated from the difference between phagocytic and resting samples.

Sensitive NBT-test-The following procedure was carried out unless otherwise mentioned. Potassium cyanide solution $(0.01 \mathrm{M}) 2 \mathrm{ml}, \mathrm{K}-\mathrm{H}$ buffer $4 \mathrm{ml}, 10$ times concentrated phosphate buffered saline $\langle 0.1 \mathrm{~m}$ phosphate, $8 \% \mathrm{NaCl}, 0.2 \% \mathrm{KCl}) 0.4 \mathrm{ml}$, and $\mathrm{H}_{2} \mathrm{O} 2.6 \mathrm{ml}$ were mixed. NBT dye $8 \mathrm{mg}$ was dissolved in the mixture and $\mathrm{pH}$ of the solution was adjusted to 7.4, which was used for an incubation solution. The incubation solution $50 \mu \mathrm{l}$, was divided into 2 series in conical centrifuge tubes with a cap. Latex suspension $\left(1.0 \times 10^{11}\right.$ particles/ml, $5 \mu \mathrm{l}$ ) was added to one series of the tubes (phagocytic series), and the same amount of $\mathrm{K}-\mathrm{H}$ buffer was added onto another series of the tubes instead of latex particles (resting series). Those tubes were preincubated at $37^{\circ}$ for $5 \mathrm{~min}$, and $50 \mu \mathrm{l}$ of the cell suspension was added to start the reaction. The reaction was allowed to proceed for $15 \mathrm{~min}$, except for time course experiment, and was stopped by the addition of $2 \mathrm{ml}$ of $0.5 \mathrm{~N}$ hydrochloric acid. The mixture was kept in ice for more than $30 \mathrm{~min}$ and then centrifuged $(1000 \mathrm{~g} \times 10$ $\mathrm{min})$. The precipitate was washed twice with $2 \mathrm{ml}$ of $0.5 \mathrm{~N}$ hydrochloric acid.

Dimethylformamide (DMF) $1 \mathrm{ml}$ was added to the precipitate, and the mixture was stirred and stood for $10 \mathrm{~min}$ at $100^{\circ}$ in a water bath to extract the NBT-fcrmazan. To increase the coloration, $1 \mathrm{ml}$ of $10 \mathrm{~N} \mathrm{KOH}$ was added onto the DMF extract and mixed thoroughly. The mixture was centrifuged $(1000 \mathrm{~g} \times 15 \mathrm{~min})$ at room temperature to separate the upper DMF layer from the lower aqueous layer. The latex was packed between the DMF and aqueous layers, so that the latex particles did not disturb the subsequent reading of optical density. Pyridine was not suitable as the solvent for the extraction after the $10 \mathrm{~N} \mathrm{KOH}$ treatment, because pyridine itself was also developed slight red color, which brought about the deviation in the results of NBT-test. Optical density of DMF layer was read at $710 \mathrm{~nm}$ against no incubation blank. NBT reducing activity was calculated from the difference between phagocytic and resting samples.

\section{Results}

\section{Effect of the Alkaline Treatment on the Coloration of NBT-formazan}

Absorption spectrum and the optical density of NBT-formazan (NBT-dye reduced form) were compared before and after the treatment with $10 \mathrm{~N} \mathrm{KOH}$. As shown in Fig. 1, the absorption of optimal NBT-formazan extracted by DMF was $515 \mathrm{~nm}$ which was the same with that extracted by pyridine. By the addition of the equal volume of $10 \mathrm{~N} \mathrm{KOH}$ onto the DMF extract the peak was shifted bathochromically from $515 \mathrm{~nm}$ to $710 \mathrm{~nm}$. NBT-formazan was prepared after the incubation of NBT solution with the cells $\left(5 \times 10^{6} / \mathrm{ml}\right)$ for $60 \mathrm{~min}$ and was extracted with pyridine. An aliquot of $0.1 \mathrm{ml}$ pyridine extract diluted with $0.9 \mathrm{ml}$ of pyridine and DMF gave almost same optical density, 0.242 and 0.245 at $515 \mathrm{~nm}$, respectively.

5) A.J. Sbarra and M.L. Karnovsky; J. Biol. Chem., 234, 1355 (1959). 
On the other hand, the sample diluted by DMF gave OD 1.18 at $710 \mathrm{~nm}$ after $10 \mathrm{~N} \mathrm{KOH}$ treatment. In other words, OD at $710 \mathrm{~nm}$ after $10 \mathrm{~N} \mathrm{KOH}$ treatment was about 4.8 times higher than that at $515 \mathrm{~nm}$. Presence of $0.1 \mathrm{ml}$ of pyridine in $\mathrm{DMF}$ solution did not interfere the optical density at both $710 \mathrm{~nm}$ and $515 \mathrm{~nm}$. To get higher sensitivity, reduction of the background coloration was attempted, because blank was around $0.37-0.50$ (in optical density at $710 \mathrm{~nm}$ ) after the treatment with $10 \mathrm{~N} \mathrm{KOH}$, which may depend on the small amount of contaminating NBT itself. This problem was solved by the reduction of the incubation mixture from $1 \mathrm{ml}$ to $100 \mu \mathrm{l}$ and complete washing of the precipitate with $0.5 \mathrm{~N}$ HCl. As the washing solution, $0.5 \mathrm{~N} \mathrm{HCl}$ was superior to ethanol, methanol and trichloroacetic acid. The absorption of the no incubation blank was reduced to around $0.04-0.07$ at $710 \mathrm{~nm}$ by this modification.

The color developed after the treatment with $10 \mathrm{~N}$ $\mathrm{KOH}$ was markedly stable up to $4 \mathrm{hr}$ as shown in Fig. 2.

\section{Effect of the Concentration of Latex Particles}

Apparent NBT reducing activity of PMN tended

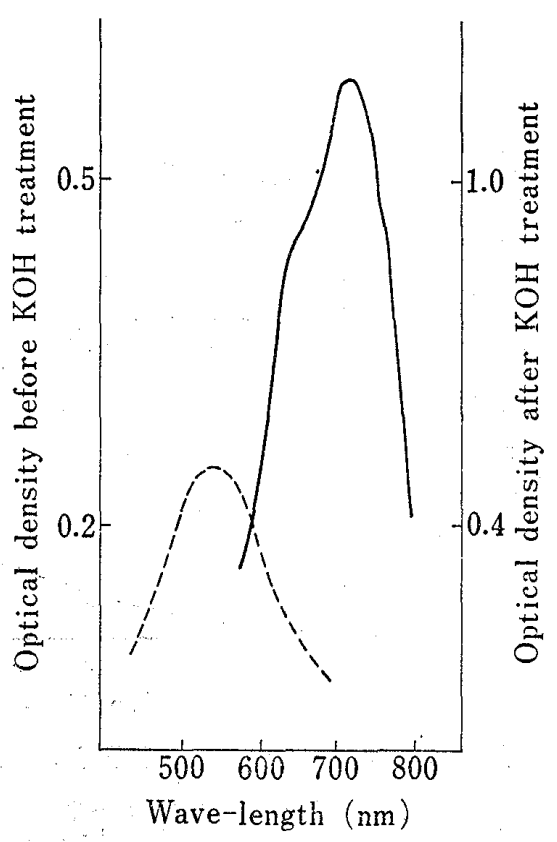

Fig. 1. Absorption Spectrum of NBT-formazan in DMF before (broken line) and after $10 \mathrm{~N}$ KOH Treatment (solid line) to increase with the number of latex particles up to $8.6 \times 10^{8}$ particles/assay in the presence of $2.6 \times 10^{5}$ cells/assay as shown by open circle in Fig. 3. In higher concentration of latex particles, however, the coloration of the blank increased slightly (closed circle). Optimal reducing activity judged from difference between the apparent activity and blank, as indicated by open triangle, was observed around $2.9-5.7 \times$ $10^{8}$ latex particle/assay.

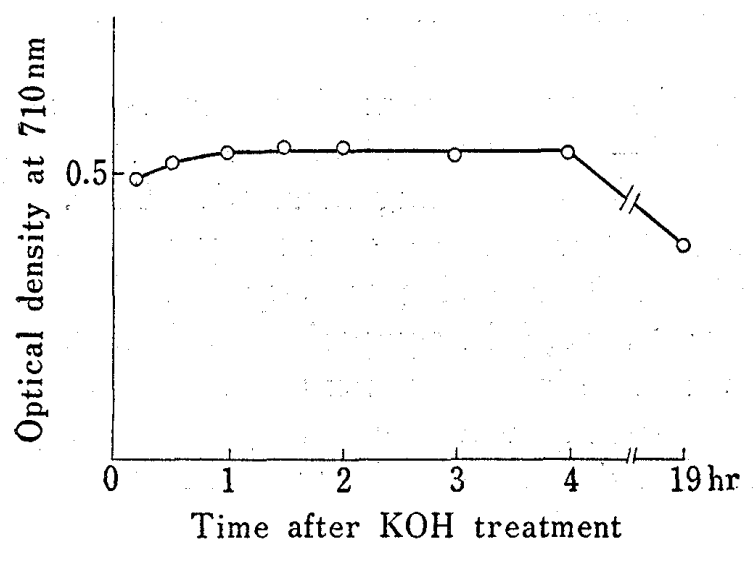

Fig. 2. Stability of the Color of NBT-formazan developed after $10 \mathrm{~N}$ KOH Treatment

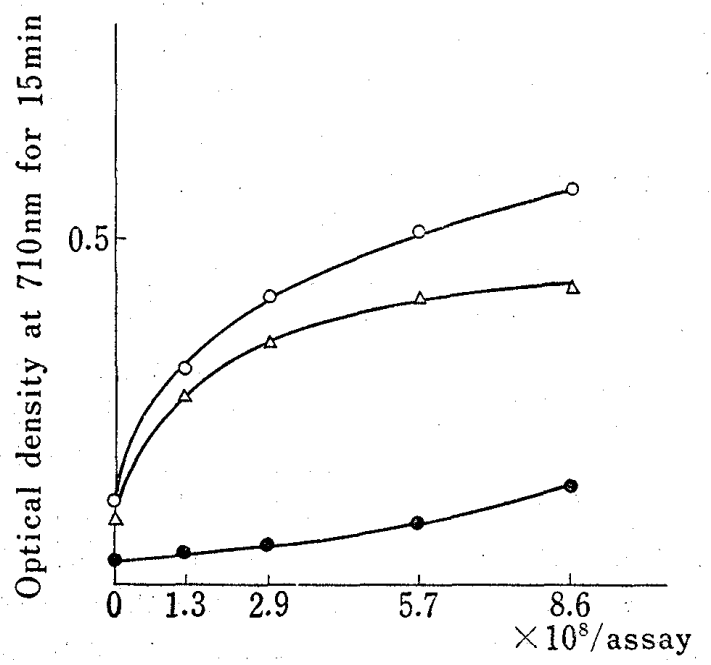

The number of latex particles

Fig. 3. Relationships between NBT reducing Activity and the Number of Latex Particles

Apparent NBT reducing activity $(\mathrm{O}-\mathrm{O})$, no incubation blank (-O), difference between apparent activity and the blank $(\triangle-\triangle)$, incubation was carried out for $15 \mathrm{~min}$ at $37^{\circ}$. 


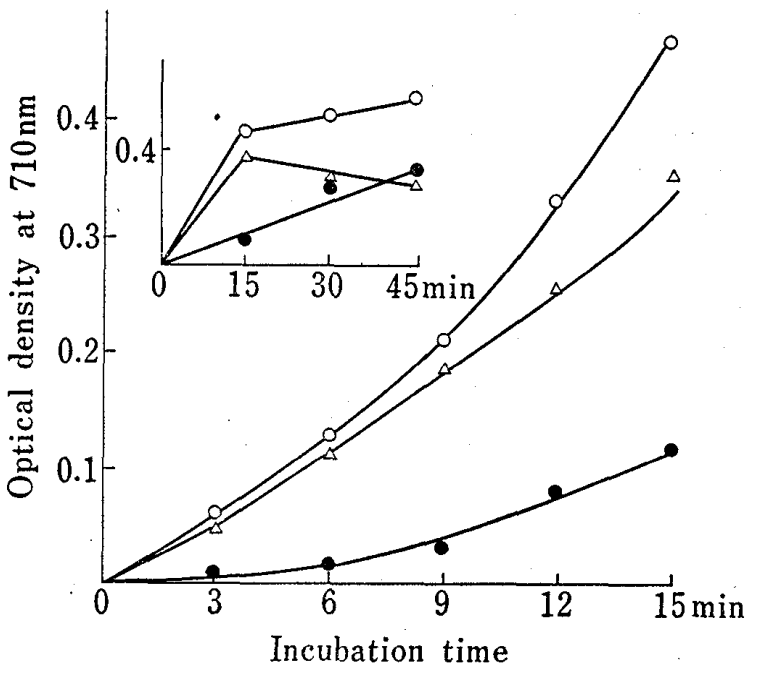

Fig. 4. Time Course of NBT reducing Activity phagocytosis $(O-O)$, resting $(-0)$, and $\triangle(O D)(\triangle-\triangle$; difference between phagocytosis and resting)

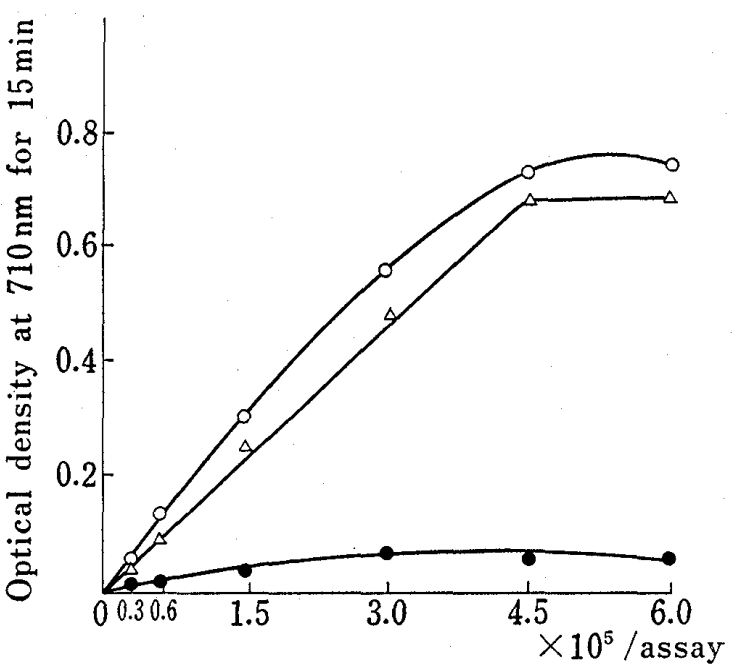

The number of PMN leukocytes

Fig. 5. Relationships between NBT reducing Activity and the Number of PMN Leukocytes

$$
\begin{aligned}
& \text { phagocytosis }(\mathrm{O}-\mathrm{O}) \text {, resting }(-\mathrm{O}) \text {, and } \triangle(\mathrm{OD}) \\
& (\triangle-\triangle \text {; difference between phagocytosis and resting). } \\
& \text { Fifteen minute incubation was carried out at } 37^{\circ} .
\end{aligned}
$$

\section{Effect of the Incubation Time and Concentration of PMN Cells}

The relationships between NBT reducing activity and incubation time were examined in the presence of PMN leukocytes $2.7 \times 10^{5} /$ assay and latex $3.9 \times 10^{8}$ particles/assay. Diffrence in the optical density between phagocytic and resting samples, linearly increased at least up to $15 \mathrm{~min}$, and declined thereafter (Fig. 4). For the quantitative NBT-test, the effect of cell numbers on the NBT reducing activity must be examined. As shown in Fig. 5, the optical density at $710 \mathrm{~nm}$ of phagocytic group increased gradually in parallel with the number of PMN leukocytes. The optical density of the resting group also increased slightly. The difference in the optical density between phagocytic and resting group, was well correlated with the cell number up to $4.5 \times 10^{5}$ /assay under this condition. All of these experiments were carried out with the use of the leukocytes from guinea pig peritoneal exudate, essentially the same results, however, were observed in leukocytes from human peripheral blood.

\section{Application to Clinical Test}

According to the newly developed sensitive assay system, clinical specimens were examined. For the preparation of PMN leukocytes, $3-5 \mathrm{ml}$ of the blood was collected from healthy subject as well as from various types of patients including those with CGD. The number of PMN cells and latex particles were $1.34 \times 10^{5}$ and $3.9 \times 10^{8}$ per assay, respectively, and incubation was carried out for $15 \mathrm{~min}$ at $37^{\circ}$. NBT reducing activity of PMN from 2 CGD patients was negligible (absorbance 0.009 on average) in comparison with that of 15 controls $(0.292 \pm 0.102)$ (Table I). PMN from various kinds of patients such as systemic lupus erythematodes, chronic granulomatous nephrosis, atypical pneumonia, abdominal pain, and nick crump gave similar activity to that of normal control. The present assay system, therefore, seems to be applicable to the detection of CGD patients.

\section{Discussion}

NBT-test was originally devised by Baehner and Nathan ${ }^{4)}$ for the detection of CGD patients who were defective in bactericidal function. This assay system has been very useful for this purpose. However, a volume as much as $15-20 \mathrm{ml}$ of blood is required for this assay. 
TABLE I. Applicability of This Method to Clinical Test

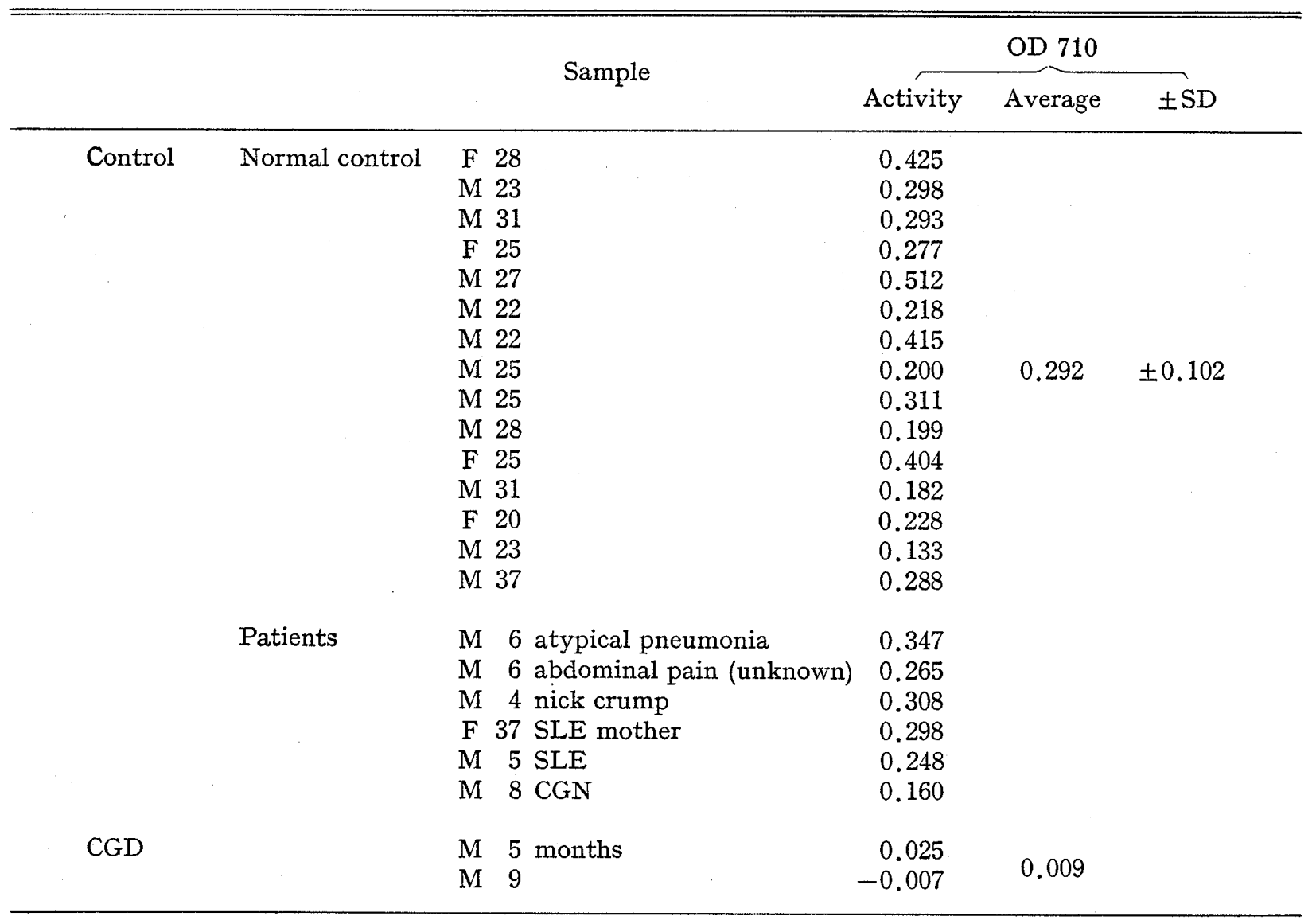

SLE: systemic lupus erythematodes, CGN: chronic granulonatous nephrosis, CGD: chronic granulomatous disease M: male, F: female

Histochemical NBT staining developed by Park, et al., ${ }^{6)}$ and Gifford and Malawista ${ }^{7)}$ is applicable to those weak patients, but this assay is inferior in quantification.

It has been assumed so far that redox reaction system has close relationship with the bactericidal mechanism ${ }^{8}$ from the result of studies on myeloperoxidase-halide system, ${ }^{2}$ ) NADPH oxidase, ${ }^{97} \mathrm{O}_{2}$ consumption, ${ }^{10)}$ and HMP shunt, ${ }^{11)}$ in PMN leukocytes. NBT reducing activity may also be involved in the bactericidal mechanism in PMN leukocytes. So, more sensitive and quantitative NBT assay system has been desired for both clinical and investigative purpose.

According to Altmann, ${ }^{12}$ ) it was shown that glycine- $\mathrm{NaOH}$ buffer ( $\mathrm{pH} 11.5$ ) treatment of the DMF extract from histochemical specimens made the bathochromic shift of the maximal absorption from $515 \mathrm{~nm}$ to $710 \mathrm{~nm}$. On basis of this finding, development of a quantitative and sensitive NBT assay system was attempted. First of all, 10N $\mathrm{KOH}$ was adopted instead of the glycine- $\mathrm{NaOH}$ buffer in these experiments, because the NBT-formazan after $10 \mathrm{~N} \mathrm{KOH}$ treatment was more stable (Fig. 2). There are further advantages of this treatment that

6) B.H. Park, S.M. Fikrig, and W. Smith, Lancet, 2, 532 (1968).

7) R.H. Gifford and S.E. Malawista, J. Lab. Clin. Med., 75, 511 (1970).

8) R.B. Johnston, B.B. Keele, H.P. Misra, J.E. Lehmeyer, L.S. Webb, R.L. Baehner, and K.V. Rajagopalan, J. Clin. Invest., 55, 1357 (1975).

9) P. Patriarca, R. Cramer, P. Dri, L. Fant, R.E. Basford, and F. Rossi, Biochim. Biophys. Acta, 53, 830 (1973).

10) R.S. Weening, D. Roos, and J.A. Loos, J. Lab. Clin. Med., 83, 570 (1974).

11) B. Holmes, A.R. Page, and R.A. Good, J. Clin. Invest., 46, 1422 (1967).

12) F.P. Altmann, Histochemie, 17, 319 (1969). 
alkaline solution neither dissolves in DMF solution nor dilutes DMF solution. Furthermore removal of latex particles could readily be achieved as the particles were packed in the interphase between DMF and $10 \mathrm{~N} \mathrm{KOH}$ in this condition.

Bathochromic shift of NBT (not reduced form) attaching nonspecifically to the cellular protein and latex particles brought about another problem of high background absorption.

This problem was almost solved by reduction of volume of the incubation mixture and washing it with $0.5 \mathrm{~N} \mathrm{HCl} 3$ times. The concentration of latex particles was also a matter to be examined. According to the ordinary assay method, high concentration of latex particles increased the turbidity which interrupted the reading of the optical density. Optimal concentration of latex particles for the assay was obtained around $2.9-5.7 \times 10^{8} /$ assay (Fig. 3), concentration of which was almost 4 times higher than that in the ordinary method. This

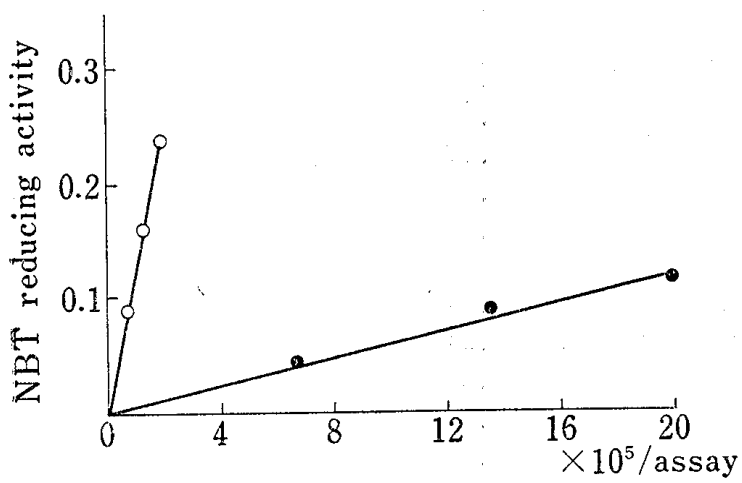

The number of PMN leukocytes

Fig. 6. Sensitivity of the newly Developed Assay in Comparison with That of the Ordinary Assay

In the modified assay $(\mathrm{O}-\mathrm{O}), 0.67,1.33$, and $2.0 \times 10^{5} \mathrm{PMN}$ cells, and $5.7 \times 10^{8}$ latex particles per assay were incubated. After $10 \mathrm{~N} \mathrm{KOH}$ treatment against NBT-formazan extracted in DMF, optical density at $710 \mathrm{~nm}$ was read. In regular assay (- - ) $6.7,13.3,20.0 \times 10^{5} \mathrm{PMN}$ cells (which is about ten times larger number of cells) and $1.3 \times 10^{8}$ latex particles per assay were incubated. NBT-formazan extracted by pyridine was read at $515 \mathrm{~nm}$. Incubation was carried out in both cases at $37^{\circ}$ for $15 \mathrm{~min}$. NBT reducing activity was calculated from the difference between phagocytosis and resting. result is well coincident with that of the studies on $\mathrm{O}_{2}$ consumption after phagocytosis of various numbers of latex particles. ${ }^{10}$ )

Sensitivity of newly developed NBTtest can be calculated in comparison with that of ordinary test. There were linear relationships between NBT reducing activity and the number of PMN leukocytes up to $2.0 \times 10^{5}$ and $20 \times 10^{5}$ in modified and ordinary assay respectively. According to the result from Fig. 6, 2.0 $\times 10^{5} \mathrm{PMN} /$ assay gave 0.231 in modified assay and $20 \times 10^{5} \mathrm{PMN} /$ assay, 0.110 in ordinary assay, indicating that the sensitivity of this test seems to be almost 20 times higher than that of the ordinary NBT-test. This sensitive assay may be apparently applicable to the analysis of CGD patients especially of the baby patients. This method may also be useful for the biochemical elucidation of the bactericidal mechanism in leukocytes.

Acknowledgement We are grateful to Prof. T. Tsubokura for giving every facility for the analysis of the blood. We are particularly indebted to Prof. T. Nakajima for helpful advise and discussion. 